\title{
PENGARUH KEWAJIBAN KEPEMILIKAN NPWP, PEMERIKSAAN PAJAK DAN PENAGIHAN PAJAK TERHADAP PENERIMAAN PAJAK (PADA KANTOR PELAYANAN PAJAK PRATAMA DI WILAYAH BATAM UTARA)
}

\author{
Faris Ramadhan, Nureska Yanuar Firdaus, Indrayani, Etty Sri Wahyuni \\ Fakultas Ekonomi Universitas Batam \\ farisramadhan@univbatam.ac.id
}

\begin{abstract}
This study aims to analyze the effect of NPWP ownership obligations, tax audit, and tax collection on tax revenue. Respondents in this study were tax officials (tax authorities) at the KPP Pratama in the North Batam area. The number of tax employees who became the sample of this study were 42 tax employees from the Primary Tax Service Office in the North Batam area. The sample determination method used in the study is the census, while the data processing method used is multiple linear regression analysis. The results of the study show that the obligation to own NPWP, tax audit and tax collection have a significant positive effect on tax revenue.
\end{abstract}

Keywords: NPWP ownership obligation, tax audit, tax collection and tax revenue

Abstrak: Penelitian ini bertujuan untuk menganalisis pengaruh kewajiban kepemilikan NPWP, pemeriksaan pajak, dan penagihan pajak terhadap penerimaan pajak. Responden dalam penelitian ini adalah para pegawai pajak (fiskus) di KPP Pratama wilayah Batam Utara. Jumlah pegawai pajak yang menjadi sampel penelitian ini adalah 42 pegawai pajak dari Kantor Pelayanan Pajak Pratama di wilayah Batam Utara. Metode penentuan sampel yang digunakan dalam penelitian adalah sensus, sedangkan metode pengolahan data yang digunakan adalah analisis regresi linier berganda. Hasil penelitian menunjukkan bahwa kewajiban kepemilikan NPWP, pemeriksaan pajak dan penagihan pajak terbukti berpengaruh positif signifikan terhadap penerimaan pajak..

Kata Kunci : Kewajiban kepemilikan NPWP, pemeriksaan pajak, penagihan pajak dan penerimaan pajak

\section{A. PENDAHULUAN}

Sebagai negara yang berkembang, sebenarnya Indonesia memiliki berbagai macam potensi untuk menjadi negara yang lebih maju. Akan tetapi pada kenyataannya Indonesia tidak bisa memanfaatkan berbagai potensi itu. Bisa dilihat kenyataannya sekarang, di Indonesia mengalami berbagai masalah hampir di semua sektor yang ada, salah satu masalah terbesar adalah masalah di sektor ekonomi, untuk memperbaiki masalah tersebut maka pajak diharapkan bisa menjadi solusi yang efektif dalam membantu permasalahan perekonomian di Indonesia. Hal ini dikarenakan pajak merupakan potensi penerimaan terbesar dalam negeri. Karena pajak merupakan penerimaan langsung yang segera bisa diolah guna untuk pembiayaan berbagai macam keperluan negara baik fasilitas sarana dan pra-sarana bagi seluruh masyarakat Indonesia (Listyaningtyas, 2012).

Dalam hal ini kontribusi penerimaan pajak terhadap penerimaan negara diharapkan menjadi semakin meningkat dari tahun ke tahun, karena seiring dengan berjalannya waktu, kian semakin menurunnya peranan minyak dan gas bumi terhadap penerimaan negara (Munari, 2005:120).

Mengacu pada uraian diatas, maka peneliti tertarik untuk melakukan penelitian mengenai pengaruh kewajiban kepemilikan NPWP, pemeriksaan pajak dan penagihan pajak terhadap penerimaan pajak pada Kantor Pelayanan Pajak (KPP) Pratama di Wilayah Batam Utara. Dengan menggunakan beberapa variabel yang berbeda dengan penelitian sebelumnya diharapkan dapat memberikan pengetahuan atau gambaran tentang pengaruh kewajiban kepemilikan NPWP, pemeriksaan pajak dan penagihan pajak terhadap penerimaan pajak. 
Rumusan Masalah Berdasarkan latar belakang masalah yang telah dikemukakan sebelumnya, maka dapat dirumuskan masalah sebagai berikut :

1. Apakah kepemilikan NPWP berpengaruh terhadap penerimaan pajak di Kantor Pajak Pratama Wilayah Batam Utara?

2. Apakah pemeriksaan pajak berpengaruh terhadap penerimaan pajak di Kantor Pajak Pratama Wilayah Batam Utara?

3. Apakah penagihan pajak berpengaruh terhadap penerimaan pajak di Kantor Pajak Pratama Wilayah Batam Utara?

4. Apakah kepemilikan NPWP, pemeriksaan pajak, dan penagihan pajak berpengaruh terhadap penerimaan pajak di Kantor Pajak Pratama Wilayah Batam Utara?

\section{Tujuan Penelitian}

Adapun yang menjadi tujuan penelitian dari penelitian ini adalah sebagai berikut :

1. Untuk mengetahui pengaruh kepemilikan NPWP terhadap penerimaan pajak di Kantor Pajak Pratama Wilayah Batam Utara.

2. Untuk mengetahui pengaruh pemeriksaan pajak terhadap penerimaan pajak di Kantor Pajak Pratama Wilayah Batam Utara.

3. Untuk mengetahui pengaruh penagihan pajak terhadap penerimaan pajak di Kantor Pajak Pratama Wilayah Batam Utara.

4. Untuk mengetahui pengaruh kepemilikan NPWP, pemeriksaan pajak, dan penagihan pajak terhadap penerimaan pajak di Kantor Pajak Pratama Wilayah Batam Utara.

\section{Manfaat Penelitian}

Berdasarkan permasalahan dan tujuan yang telah dikemukakan, maka manfaat yang dapat diperoleh dari penelitian ini adalah sebagai berikut :

1. Manfaat teoritis

a. Untuk menambah khazanah ilmu pengetahuan khususnya dalam bidang akuntansi perpajakan.

b. Untuk memenuhi syarat dalam mencapai gelar sarjana ekonomi program study akuntansi pada Universitas Batam.

2. Manfaat Praktis

a. Bagi peneliti sangat bermanfaat untuk melatih dan mengembangkan kemampuan berfikir ilmiah dan sistematis melalui penulisan karya ilmiah dibidang ilmu akuntansi.

b. Bagi Kantor Pelayanan Pajak (KPP), Untuk memberikan evaluasi dan masukan yang dapat berguna mengenai bagaimana pengaruh kewajiban kepemilikan NPWP, pemeriksaan pajak dan penagihan pajak terhadap penerimaan pajak yang telah dilakukan.

\section{KERANGKA TEORI, KERANGKA KONSEPTUAL, MODEL PENELITIAN DAN HIPOTESIS}

\section{Nomor Pokok Wajib Pajak (NPWP)}

Nomor pokok wajib pajak (NPWP) adalah nomor yang diberikan kepada wajib pajak sebagai sarana dalam administrasi perpajakan yang dipergunakan sebagai tanda pengenal diri atau identitas wajib pajak dalam melaksanakan hak dan kewajiban perpajakannya (Mardiasmo, 2009:23)

\section{Pemeriksaan pajak}

Pengertian pemeriksaan menurut Undang-undang Nomor 28 Tahun 2007 dikutip dari Pardiat (2008:11) adalah sebagai berikut:

"Pemeriksaan pajak adalah serangkaian kegiatan menghimpun dan mengolah data, keterangan dan/atau bukti yang dilaksanakan secara objektif dan profesional berdasarkan suatu standar 
pemeriksaan untuk menguji kepatuhan pemenuhan kewajiban perpajakan dan/atau untuk tujuan lain dalam rangka melaksanakan ketentuan peraturan perundang-undangan perpajakan.

\section{Penagihan Pajak}

Pengertian dalam pasal 1 butir 9 Undang-undang No. 19 Tahun 2000 penagihan pajak adalah serangkaian tindakan agar penanggung pajak melunasi utang pajak dan biaya penagihan pajak dengan menegur atau memperingatkan, melaksanakan penagihan seketika dan sekaligus memberitahukan surat paksa, mengusulkan pencegahan, melaksankaan penyitaan, melaksanakan penyanderaan, menjual barang yang telah disita (Rahayu, 2010:197).

\section{Kerangka Konseptual}

\section{Pengaruh Kewajiban Kepemilikan NPWP Terhadap Penerimaan Pajak}

Penelitian yang dilakukan oleh Setyawan (2009:15) dan Sujatmiko (2011) menyatakan bahwa kepemilikan NPWP berhubungan positif terhadap penerimaan pajak Nomor pokok wajib pajak (NPWP) merupakan nomor yang diberikan kepada wajib pajak sebagai sarana dalam administrasi perpajakan yang dipergunakan sebagai tanda pengenal diri atau identitas wajib pajak dalam melaksanakan hak dan kewajiban perpajakannya. Menurut Setiawan (2009:20), pengesahan pemberian NPWP dilakukan dengan pemberian Surat Keterangan Terdaftar. Surat tersebut menginformasikan pemenuhan kewajiban perpajakan setiap wajib pajak. Berdasarkan hasil penelitian petugas Seksi Tata Usaha Perpajakan, kewajiban perpajakan tersebut diisi dan harus dilaknakan oleh setiap wajib pajak. Pengisian kewajiban perpajakan harus didasarkan pada ketentuan peraturan perundang-undangan perpajakan yang berlaku, sehingga pelaksanaan atas kewajiban perpajakan oleh setiap wajib pajak dapat mengamankan penerimaan pajak. Semakin banyak yang diisi kewajiban perpajakan oleh petugas secara benar dan tepat maka penerimaan pajak dapat meningkat.

\section{Pengaruh Pemeriksaan Pajak Terhadap Penerimaan Pajak}

Pemeriksaan pajak merupakan serangkaian kegiatan menghimpun dan mengolah data, keterangan dan/atau bukti yang dilaksanakan secara objektif dan profesional berdasarkan suatu standar pemeriksaan untuk menguji kepatuhan pemenuhan kewajiban perpajakan dan/atau untuk tujuan lain dalam rangka melaksanakan ketentuan peraturan perundang- undangan perpajakan. Sebagaimana penelitian yang telah dilakukan oleh Sukirman (2011:12) bahwa pemeriksaan pajak secara nominal telah meningkatkan penerimaan pajak dan menurut penelitian Herryanto dan Agus Arianto Toly (2013) dengan judul "pengaruh kesadaran wajib pajak, kegiatan sosialisasi perpajakan dan pemeriksaan pajak terhadap penerimaan pajak penghasilan di KPP Pratama Surabaya Sawahan" menunjukkan bahwa variabel pemeriksaan pajak memiliki nilai signifikan t sebesar 0,023 . Angka tersebut lebih kecil dari 0,05 sehingga terdapat pengaruh dari pemeriksaan pajak terhadap penerimaan pajak.

\section{Pengaruh Penagihan Pajak Terhadap Penerimaan Pajak}

Di dalam penelitian yang dilakukan oleh Vegirawati (2011:5) menyatakan bahwa korelasi jumlah penerbitan STP dengan Penerimaan Pajak mempunyai korelasi yang signifikan Gisijanto (2008:10) menyatakan bahwa penagihan pajak dengan surat paksa berpengaruh secara signifikan terhadap penerimaan pajak, yang menunjukkan bahwa jumlah penerimaan pajak penghasilan (PPh) Badan di KPP Pratama Kanwil DJP Jakarta Pusat terus mengalami peningkatan dari tahun ketahun. Namun Peningkatan tersebut belum dicapai secara optimal, hal ini terlihat dari realisasi dibandingkan target penerimaan pajak penghasilan badan, adapun variabel yang paling besar memberikan kontribusi pengaruh terbesar terhadap penerimaan PPh Badan adalah penagihan pajak.

\section{Model Penelitian}


Berdasarkan teori-teori tersebut di atas, maka dapat dikemukakan alur pemikiran tentang kepemilikan NPWP, Pemeriksaan Pajak dan Penagihan Pajak terhadap Penerimaan Pajak kedalam model penelitian sebagai berikut :

\section{Gambar 2.1. Model Penelitian}

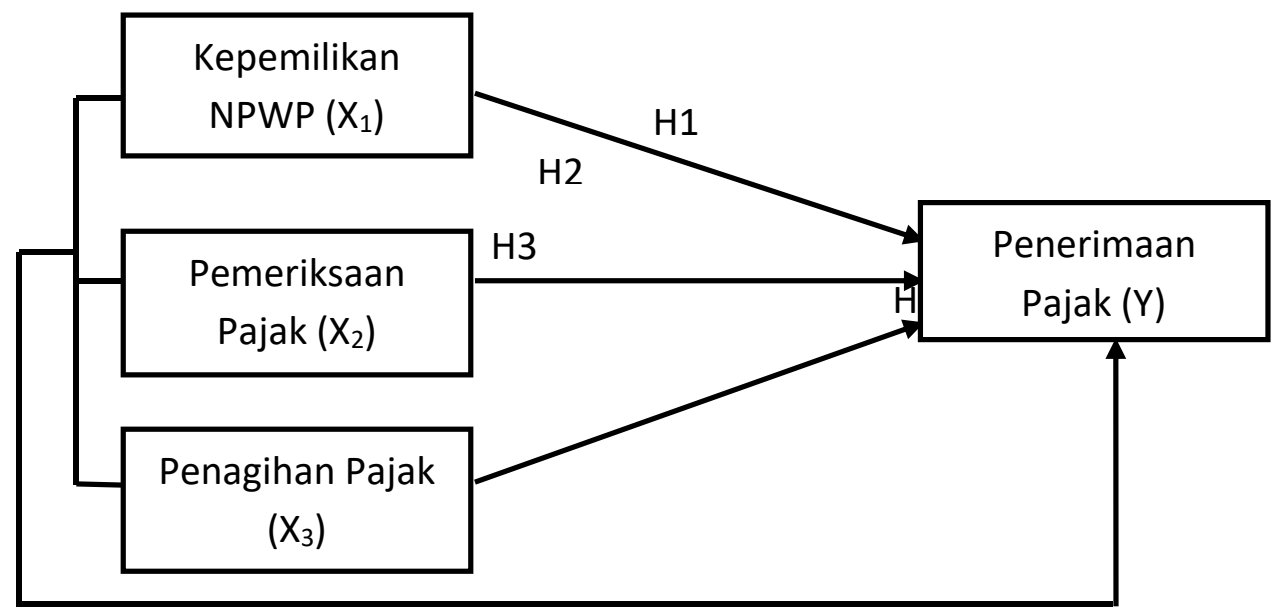

Hipotesis

Berdasarkan uraian diatas maka hipotesis dapat di artikan sebagai suatu jawaban yang bersifat sementara terhadap permasalahan penelitian, sampai data terkumpul dan dapat dibuktikan kebenarannya. Sehubungan dengan identifikasi masalah, rumusan dan batasan masalah di atas maka penulis mengambil hipotesis dalam penelitian ini sebagai berikut :

H1 : Kewajiban Kepemilikan NPWP memiliki pengaruh terhadap penerimaan pajak.

H2 : Pemeriksaan pajak memiliki pengaruh terhadap penerimaan pajak.

H3 : Penagihan pajak memiliki pengaruh terhadap penerimaan pajak.

H4 : Kewajiban Kepemilikan NPWP, pemeriksaan pajak dan penagihan pajak secara simultan memiliki pengaruh terhadap penerimaan pajak.

\section{B. METODOLOGI PENELITIAN}

\section{Tempat Penelitian}

Obyek penelitian skripsi ini adalah Pegawai Kantor Pelayanan Pajak Pratama di Wilayah Batam Utara. Penelitian ini akan dilakukan dalam rentang waktu 2 bulan dan dimulai dengan tahapan pengajuan judul, pengajuan proposal, sidang proposal dan seterusnya.

\section{Metode Penelitian}

Metode penelitian yang akan digunakan dalam penelitian ini yaitu metode dengan analisis kualitatif. Sumber primer adalah sumber data yang langsung memberikan data kepada pengumpul data (Sugiyono, 2018:103). Metode data primer yang digunakan yaitu metode survey dengan teknik kuesioner (questionnaires) dan wawancara (interview).

\section{Teknik Pengumpulan Data}

Metode data primer yang digunakan yaitu metode survey dengan teknik kuesioner (questionnaires) dan wawancara (interview). 
Populasi Sampel Populasi yang dimaksud dalam penelitian ini adalah pegawai pajak yang ada pada KPP Pratama Wilayah Batam Utara yang berjumlah 42 orang ppegawai dan dalam penelitian ini sampel ditentukan secara sensus, yang artinya menggunakan seluruh populasi sebagai penelitian.

\section{Metode Analisis Data}

Metode analisis data menggunakan statistik deskriptif, uji kualitas data, dan uji hipotesis.

\section{HASIL PENELITIAN DAN PEMBAHASAN}

\section{Gambaran Umum KPP Pratama Batam Utara}

Pada penelitian ini, peneliti melakukan penelitian pada pegawai pajak di Kantor Pelayanan Pajak Pratama Wilayah Batam Utara sebanyak 42 Orang. Peneliti melakukan penelitian di Kantor Pelayanan Pajak Pratama Wilayah Batam Utara karena dianggap mampu memberikan data yang dibutuhkan dalam penelitian, terkait dengan fenomena yang telah diangkat pada latar belakang.

\section{Deskripsi Statistik}

Tabel 4.5

\section{Descriptive Statistics}

\begin{tabular}{|l|l|r|r|r|r|r|}
\hline & N & Range & Minimum & Maximum & Mean & Std. Deviation \\
\hline Kewajiban Kepemilikan NPWP & 42 & 5.0 & 23.0 & 28.0 & 25.810 & 1.4354 \\
Pemeriksaan Pajak & 42 & 8.0 & 22.0 & 30.0 & 26.095 & 2.3665 \\
Penagihan Pajak & 42 & 6.0 & 21.0 & 27.0 & 24.310 & 1.4565 \\
Penerimaan Pajak & 42 & 9.0 & 21.0 & 30.0 & 26.262 & 2.7414 \\
Valid N (listwise) & 42 & & & & & \\
\hline
\end{tabular}

Berdasarkan table 4.5 diatas dapat diketahui nilai Range variabel Kewajiban Kepemilikan NPWP sebesar 5 dengan nilai minimum 23 dan nilai maximum 28 . dapat diketahui nilai Range variable Pemeriksaan Pajak sebesar 8 dengan nilai minimum 22 dan nilai maximum 30. Range variabel Penagihan Pajak sebesar 6 dengan nilai minimum 21 dan nilai maximum 27. Diketahui nilai range variabel Penerimaan Pajak sebesar 9 dengan nilai minimum 21 dan nilai maximum 30.

Uji Validitas

\section{Uji Kualitas Data}

Berdasarkan pengolahan data yang dilakukan diperoleh data hasil uji validitas sebagai berikut :

Tabel 4.6

Hasil Uji Validitas

\begin{tabular}{|c|c|l|c|}
\hline No Soal & $\begin{array}{c}\text { R } \\
\text { hitung }\end{array}$ & R Tabel & Keterangan \\
\hline X1.1 & 0,451 & 0,3044 & Valid \\
\hline X1.2 & 0,629 & 0,3044 & Valid \\
\hline X1.3 & 0,534 & 0,3044 & Valid \\
\hline X1.4 & 0,485 & 0,3044 & Valid \\
\hline X1.5 & 0,338 & 0,3044 & Valid \\
\hline X1.6 & 0,390 & 0,3044 & Valid \\
\hline
\end{tabular}




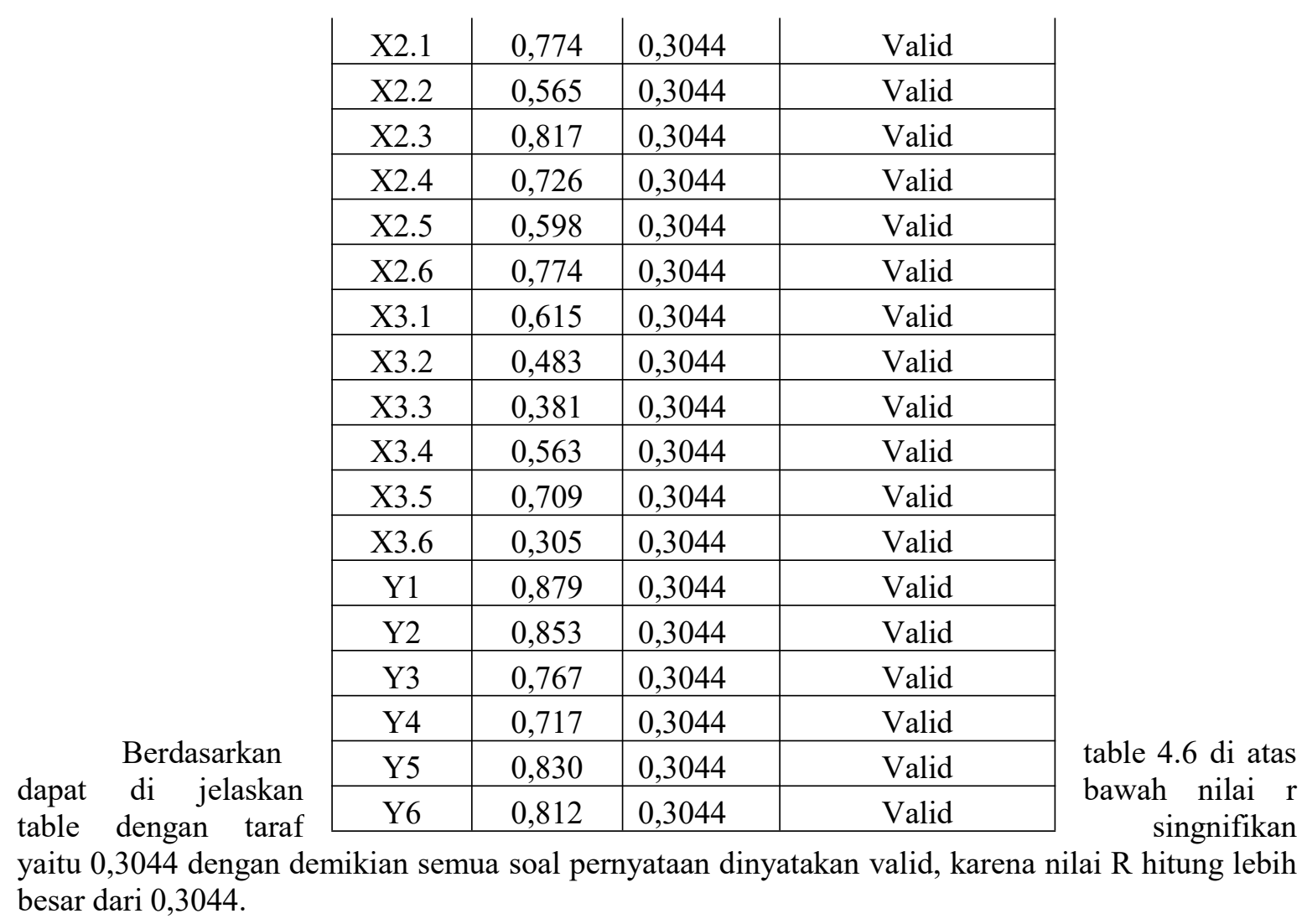

\section{Uji Reliabilitas}

Tabel 4.7

\section{Hasil Uji Reliabilitas}

\begin{tabular}{|c|l|c|l|}
\hline No & Variabel & $\begin{array}{c}\text { Hasil } \\
\text { Uji }\end{array}$ & Keterangan \\
\hline 1 & $\begin{array}{l}\text { Kewajiban Kepemilikan } \\
\text { NPWP }\end{array}$ & 0,680 & Baik/realibel \\
\hline 2 & Pemeriksaan Pajak & 0,774 & Diterima/realibel \\
\hline 3 & Penagihan Pajak & 0,712 & Diterima/realibel \\
\hline 4 & Penerimaan Pajak & 0,801 & Baik/realibel \\
\hline
\end{tabular}

Berdasarkan Tabel 4.7 diatas dapat di jelaskan bahwa nilai koefisien alpha Kewajiban Kepemilikan NPWP sebesar 0.680, Pemeriksaan Pajak sebesar 0.774, Penagihan Pajak sebesar 0.712 dan Penerimaan Pajak sebesar 0.801. nilai alpha lebih besar daripada 0.6 sehingga dapat dikatakan bahwa semua instrumen penelitian ini adalah realibel. 


\section{Uji Asumsi Klasik}

\section{Uji Normalitas}

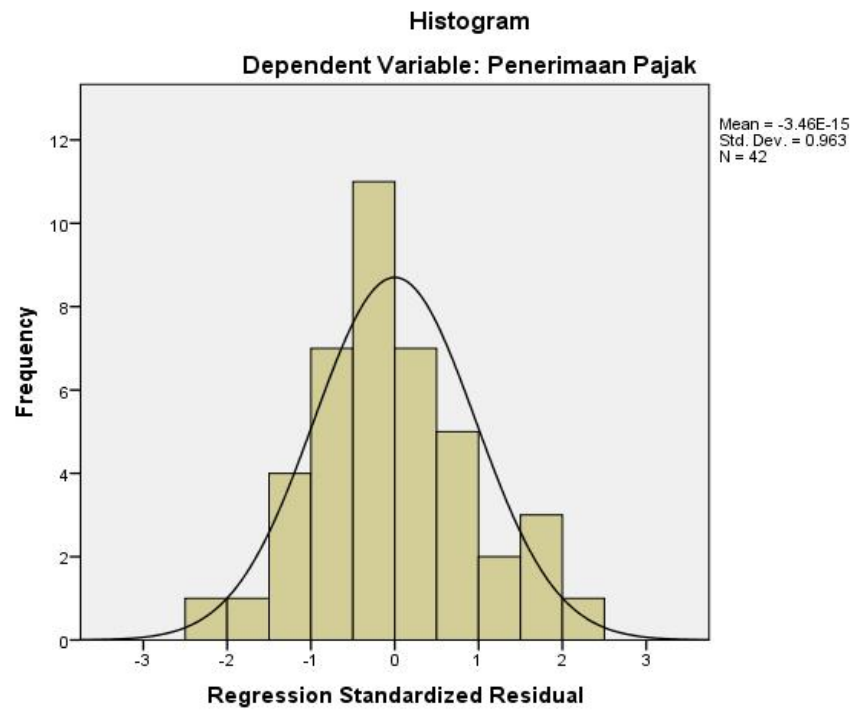

\section{Gambar 4.1}

\section{Hasil Uji Normalitas Dalam Histogram}

Bedasarkáı yalıuvaı 4.1 u uatas, ıası ujı nuınıaıtas uaıam histogram residual Menunjukkan bahwa data distribusi normal karena grafik membentuk lonceng yang merupakan syarat untuk dapat dilakukan uji regresi. Atau bisa juga dilihat dari jika penyebaran data mengikuti garis diagonal pada grafik p-plot sebagai berikut:

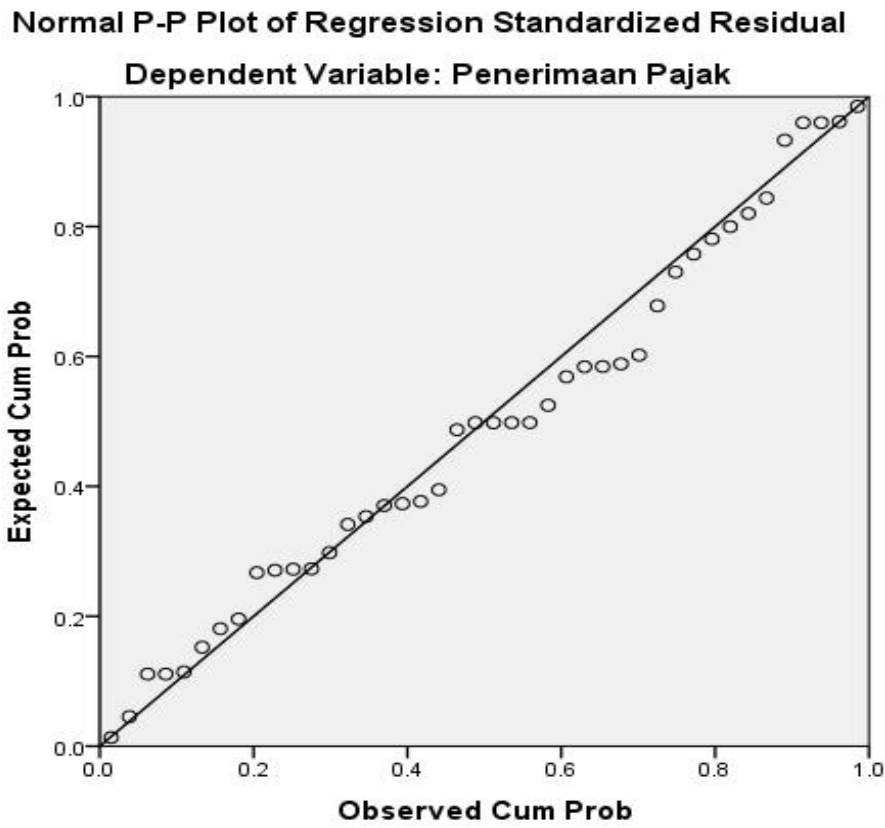




\section{Gambar 4.2}

Hasil Uji.Normalitas Dalam P-plot
Gambar diatas merupakan hasil uji normalitas data unttk semua dimensi secara simultan terhadap Kualitas Audit. Dapat dilihat titik-titik menyebar sekitar garis diagonal dan penyebarannya mengikuti arah garis diagonal, yang berarti nilai residual berdistribusi normal, sehingga model regresi layak dipakai untuk mempredeksi Penerimaan Pajak berdasarkan masukan semua variabel bebas.

\section{Uji Multikolinieritas}

\section{Tabel 4.8}

Hasil Uji Multikolinieritas

Coefficientsa

\begin{tabular}{|c|c|c|c|c|c|c|c|}
\hline \multirow[b]{2}{*}{ Model } & \multicolumn{2}{|c|}{$\begin{array}{l}\text { Unstandardize } \\
\text { d Coefficients }\end{array}$} & \multirow{2}{*}{$\begin{array}{c}\text { Standardized } \\
\text { Coefficients } \\
\text { Beta } \\
\end{array}$} & \multirow[b]{2}{*}{$\mathrm{T}$} & \multirow[b]{2}{*}{ Sig. } & \multicolumn{2}{|c|}{$\begin{array}{l}\text { Collinearity } \\
\text { Statistics }\end{array}$} \\
\hline & B & $\begin{array}{l}\text { Std. } \\
\text { Error }\end{array}$ & & & & Tolerance & VIF \\
\hline 1 (Constant) & 25.118 & $\begin{array}{r}6.53 \\
6\end{array}$ & & 3.843 & .000 & & \\
\hline $\begin{array}{l}\text { Kewajiban } \\
\text { Kepemilikan } \\
\text { NPWP }\end{array}$ & .567 & .221 & .297 & 2.568 & .014 & .821 & 1.219 \\
\hline $\begin{array}{l}\text { Pemeriksaan } \\
\text { Pajak }\end{array}$ & 1.103 & .155 & .952 & 7.121 & .000 & .614 & 1.630 \\
\hline $\begin{array}{l}\text { Penagihan } \\
\text { Pajak }\end{array}$ & .535 & .233 & .284 & 2.301 & .027 & .719 & 1.391 \\
\hline
\end{tabular}

a. Dependent Variable: Penerimaan Pajak

Sumber : Data SPSS yang diolah 2018

Dari Tabel 4.8 di atas dapat diketahui bahwa VIF dari Kewajiban Kepemilikan NPWP sebesar 1,219, untuk Pemeriksaan Pajak 1,630 dan Penagihan Pajak 1,391. Hasil ini menunjukkan bahwa tidak terdapat variabel yang memilki multikolinieritas dikarenakan VIF tidak ada melebihi dari nilai batas toleransi yang ditentukan (tidak melebihi 4 atau 5). Mulitikolineritas artinya terdapat kolerasi yang besar diantara variabel bebas.

\section{Uji Heterokedastisitas}

Untuk mendeteksi ada tidaknya heterokedasitas pada suatu model dapat dilihat dari pola gambar Scaterplot model tersebut. Tidak terdapat heterokedastisitas jika :

1. Penyebaran titik-titik data sebaiknya tidak berpola.

2. Titik-titik data menyebar di atas dan di bawah dan sekitar angka 0 .

3. Titik-titik data tidak mengumpul hanya di atas atau di bawah saja. 


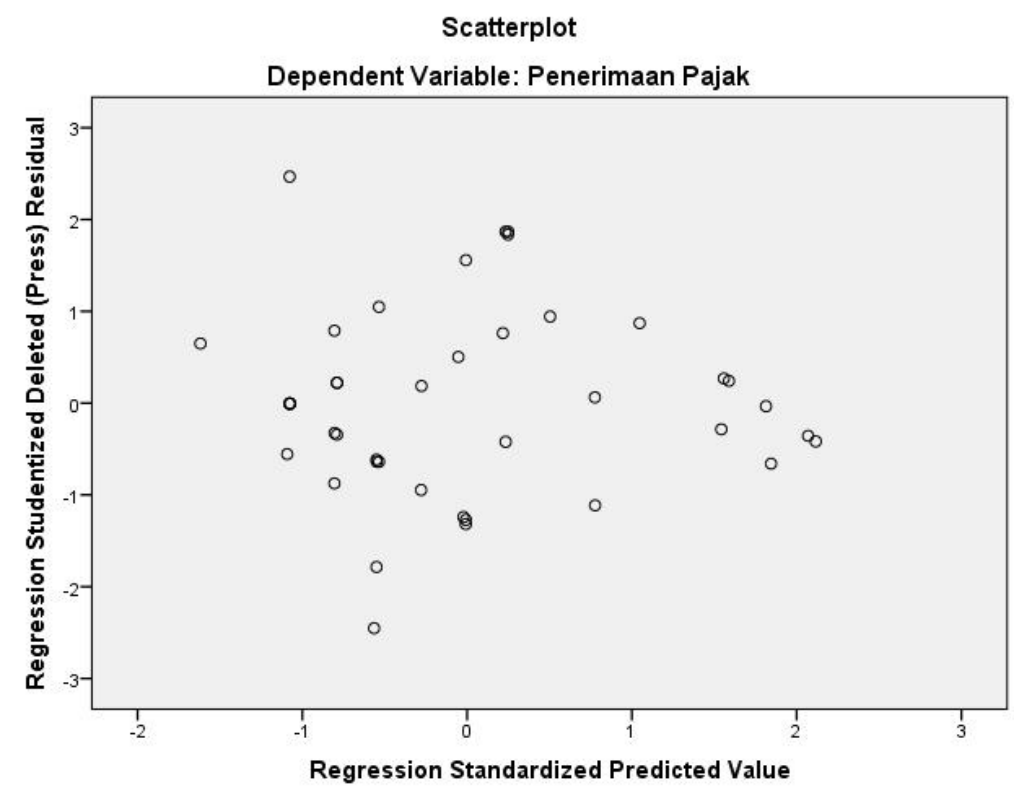

Gambar 4.3 : Hasil Uji Heterokedastisitas

Berdasarkan gambar 4.3 di atas dapat disimpulkan bahwa penelitian ini terbebas dari asumsi klasi heterokedastisitas dikarenakan titik-titik data tidak berpola dan menyebar di atas dan di bawah atau sekitar angka 0 .

\section{Autokorelasi}

Uji autokorelasi adalah untuk melihat apakah terjadi korelasi antara suatu periode $t$ dengan periode sebelumnya $(\mathrm{t}-1)$. Secara sederhana adalah bahwa analisis regresi adalah untuk melihat pengaruh antara variabel bebas terhadap variabel terikat, jadi tidak boleh ada korelasi antara observasi dengan data observasi sebelumnya.

Tabel 4.9

\section{Hasil Uji Koefisiensi Determinasi}

\begin{tabular}{|l|c|c|r|r|c|}
\multicolumn{7}{|c|}{ Model Summary $^{\mathbf{b}}$} \\
Model & $\mathrm{R}$ & $\begin{array}{c}\mathrm{R} \\
\text { Square }\end{array}$ & $\begin{array}{c}\text { Adjusted R } \\
\text { Square }\end{array}$ & $\begin{array}{c}\text { Std. Error of the } \\
\text { Estimate }\end{array}$ & $\begin{array}{c}\text { Durbin- } \\
\text { Watson }\end{array}$ \\
\hline 1 & $.764^{\mathrm{a}}$ & .583 & .550 & 1.8386 & 1.742 \\
\hline
\end{tabular}

a. Predictors: (Constant), Penagihan Pajak, Kewajiban Kepemilikan NPWP, Pemeriksaan Pajak

b. Dependent Variable: Penerimaan Pajak

Kriteria pengambilan keputusan pengujian autokorelasi adalah sebagai berikut:

a. Angka D-W dibawah -2 berarti ada autokorelasi positif.

b. Angka D-W diantara -2 sampai +2 berarti tidak ada autokorelasi.

c. Angka D-W diatas +2 berarti ada autokorelasi negatif.

Dari hasil tabel 4.9 tersebut dapat dilihat Durbin-watson menunjukan nilai sebesar 1.742 dari hasil tersebut dapat disimpulkan bahwa DW berada diantara -2 sampai +2 berati tidak ada autokorelasi. 


\section{Uji Hipotesis}

Analisis linier berganda yaitu untuk menganalisa seberapa besar pengaruh antara beberapa variabel bebas (Independent variable). Bentuk umum persamaan regresi berganda adalah sebagai berikut :

$$
\mathrm{Y}=\mathrm{a}+\mathrm{b} 1 \mathrm{X} 1+\mathrm{b} 2 \mathrm{X} 2+\mathrm{b} 3 \mathrm{X} 3+\mathrm{e}
$$

Keterangan :

$$
\begin{aligned}
& \mathrm{Y}=\text { Variabel dependen ( Penerimaan Pajak) } \\
& \mathrm{a}=\text { Konstanta } \\
& \mathrm{b}=\text { Koefisien Regresi } \\
& \mathrm{X} 1=\text { Variabel independent ( Kewajiban Kepemilikan NPWP }) \\
& \mathrm{X} 2=\text { Variabel Independent ( Pemeriksaan Pajak ) } \\
& \mathrm{X} 3=\text { Variabel Indepandent ( Penagihan Pajak) } \\
& \mathrm{e}=\text { Error / Variabel yang tidak diajukan dalam penelitian }
\end{aligned}
$$

\begin{tabular}{|c|c|c|c|c|c|c|c|}
\hline \multirow[b]{2}{*}{ Model } & \multicolumn{2}{|c|}{$\begin{array}{l}\text { Unstandardize } \\
\text { d Coefficients }\end{array}$} & \multirow{2}{*}{$\begin{array}{c}\text { Standardized } \\
\text { Coefficients } \\
\text { Beta }\end{array}$} & \multirow[b]{2}{*}{$\mathrm{T}$} & \multirow[b]{2}{*}{ Sig. } & \multicolumn{2}{|c|}{$\begin{array}{l}\text { Collinearity } \\
\text { Statistics }\end{array}$} \\
\hline & B & $\begin{array}{l}\text { Std. } \\
\text { Error }\end{array}$ & & & & Tolerance & VIF \\
\hline 1 (Constant) & 25.118 & $\begin{array}{r}6.53 \\
6\end{array}$ & & 3.843 & .000 & & \\
\hline $\begin{array}{l}\text { Kewajiban } \\
\text { Kepemilikan } \\
\text { NPWP }\end{array}$ & .567 & .221 & .297 & 2.568 & .014 & .821 & 1.219 \\
\hline $\begin{array}{l}\text { Pemeriksaan } \\
\text { Pajak }\end{array}$ & 1.103 & .155 & .952 & 7.121 & .000 & .614 & 1.630 \\
\hline $\begin{array}{l}\text { Penagihan } \\
\text { Pajak }\end{array}$ & .535 & .233 & .284 & 2.301 & .027 & .719 & 1.391 \\
\hline
\end{tabular}

Tabel 4.10

Hasil Uji Regresi Linier Berganda

Coefficientsa

a. Dependent Variable: Penerimaan Pajak

Sumber : Data SPSS yang diolah 2018

Berdasarkan hasil pengujian parameter individu yang di sajikan dalam tabel di atas, maka dapat dikembangkan sebuah model regresi sebagai berikut :

$$
\mathrm{Y}=25,118+0,567 \mathrm{X} 1+1,103 \mathrm{X} 2+0,535 \mathrm{X} 3+\mathrm{e}
$$

Dari persamaan regresi di atas, maka dapat diuraikan sebagai berikut :

1. Nilai konstanta (a) untuk persamaan regresi sebesar 25,118 dengan parameter positif. Hal ini berarti jika Kewajiban Kepemilikan NPWP (X1), Pemeriksaan Pajak (X2) Penagihan Pajak (X3) sama dengan nol, maka nilai Penerimaan Pajak (Y) di Kantor Pelayanan Pajak Pratama Wilayah Batam Utara sebesar 25,118.

2. Koefisien bernilai positif artinya terjadi pengaruh positif antara Kewajiban Kepemilikan NPWP terhadap Penerimaan Pajak. Koefesien b1=0,567 dengan nilai signifikan 0,014< 0,05 yang berarti menunjukkan peningkatan 1 satuan Kewajiban Kepemilikan NPWP akan meningkatkan Penerimaan Pajak sebesar 0,567 dengan asumsi variabel-variabel bebas lainnya konstan.

3. Koefisien bernilai positif artinya terjadi pengaruh positif antara Pemeriksaan Pajak terhadap Penerimaan Pajak. Koefesien $\mathrm{b} 2=1,103$ dengan nilai signifikan $0,000<0,05$ yang berarti menunjukan peningkatan 1 satuan Pemeriksaan Pajak sebesar 1,103 dengan asumsi variabel-variabel bebas lainnya konstan. 
4. Koefisien bernilai positif artinya terjadi pengaruh positif antara Penagihan Pajak terhadap Penerimaan Pajak. Koefesien b3=0,535 dengan nilai signifikan 0,027<0,05 yang berarti menunjukan peningkatan 1 satuan Pemeriksaan Pajak sebesar 0,535 dengan asumsi variabel-variabel bebas lainnya konstan.

\section{Uji Signifikansi Parsial (Uji Statistik t)}

Uji t-test digunakan untuk menguji apakah variabel independent berpengaruh secara parsial terhadap variabel terikat (Dependent Variable)). Berikut hasil uji t :

Tabel 4.11

Hasil Uji Statistik t

\section{Coefficientsa}

\begin{tabular}{|c|c|c|c|c|c|c|c|}
\hline \multirow[b]{2}{*}{ Model } & \multicolumn{2}{|c|}{$\begin{array}{l}\text { Unstandardize } \\
\text { d Coefficients }\end{array}$} & \multirow{2}{*}{$\begin{array}{c}\text { Standardized } \\
\text { Coefficients } \\
\text { Beta } \\
\end{array}$} & \multirow[b]{2}{*}{$\mathrm{t}$} & \multirow[b]{2}{*}{ Sig. } & \multicolumn{2}{|c|}{$\begin{array}{l}\text { Collinearity } \\
\text { Statistics }\end{array}$} \\
\hline & B & $\begin{array}{l}\text { Std. } \\
\text { Error }\end{array}$ & & & & Tolerance & VIF \\
\hline 1 (Constant) & 25.118 & $\begin{array}{r}6.53 \\
6\end{array}$ & & 3.843 & .000 & & \\
\hline $\begin{array}{l}\text { Kewajiban } \\
\text { Kepemilikan } \\
\text { NPWP }\end{array}$ & .567 & .221 & .297 & 2.568 & .014 & .821 & 1.219 \\
\hline $\begin{array}{l}\text { Pemeriksaan } \\
\text { Pajak }\end{array}$ & 1.103 & .155 & .952 & 7.121 & .000 & .614 & 1.630 \\
\hline $\begin{array}{l}\text { Penagihan } \\
\text { Pajak }\end{array}$ & .535 & .233 & .284 & 2.301 & .027 & .719 & 1.391 \\
\hline
\end{tabular}

a. Dependent Variable: Penerimaan Pajak berikut:

Berdasarkan hasil statistik pada pada Tabel 4.11 di atas dapat di jelaskan bahwa sebagai

1. Kewajiban Kepemilikan NPWP

Berdasarkan tabel diatas didapati nilai t hitung sebesar 2.568 dengan nilai signifikan 0.014 dimana lebih kecil dari 0,05 maka kewajiban kepemilikan NPWP berpengaruh signifikan terhadapat penerimaan pajak sehingga $\mathrm{H} 1$ diterima.

2. Pemeriksaan Pajak

Berdasarkan tabel diatas didapati nilai t hitung sebesar 7.121 dengan nilai signifikan 0.000 dimana lebih kecil dari 0,05 maka kewajiban kepemilikan NPWP berpengaruh signifikan terhadapat penerimaan pajak sehingga $\mathrm{H} 2$ diterima.

3. Penagihan Pajak

Berdasarkan tabel diatas didapati nilai t hitung sebesar 2.301 dengan nilai signifikan 0.027 dimana lebih kecil dari 0,05 maka kewajiban kepemilikan NPWP berpengaruh signifikan terhadapat penerimaan pajak sehingga $\mathrm{H} 3$ diterima.

\section{Uji signifkansi Simultan (Uji Statistik F)}

Uji F digunakan untuk menguji pengaruh variabel bebas (Independent Variable) terhadap variabel terikat (Dependent Variable) secara bersama-sama. Dapat dilihat pada Tabel 4.8 di bawah ini : 
Tabel 4.12

Hasil Uji F Test

\begin{tabular}{|c|c|c|c|c|c|}
\hline \multicolumn{6}{|c|}{ ANOVA $^{\mathrm{a}}$} \\
\hline Model & Sum of Squares & Df & Mean Square & $\mathrm{F}$ & Sig. \\
\hline 1 Regression & 179.667 & 3 & 59.889 & 17.717 & $.000^{\mathrm{b}}$ \\
\hline Residual & 128.452 & 38 & 3.380 & & \\
\hline Total & 308.119 & 41 & & & \\
\hline
\end{tabular}

a. Dependent Variable: Penerimaan Pajak

b. Predictors: (Constant), Penagihan Pajak, Kewajiban Kepemilikan NPWP, Pemeriksaan Pajak

Berdasarkan hasil statistik pada pada Tabel 4.12 di atas dapat di tarik kesimpulan bahwa nilai signifikan sebesar 0.000 lebih kecil dari 0,05 maka dapat disimpulkan secara bersama-sama variabel Kewajiban Kepemilikan NPWP, Pemeriksaan Pajak, Penagihan Pajak berpengaruh signifikan terhadap Penerimaan Pajak oleh karena itu H4 yang menyatakan Kewajiban Kepemilikan NPWP, Pemeriksaan Pajak, Penagihan Pajak berpengaruh secara simultan terhadap Penerimaan Pajak dan signifikan dapat diterima.

\section{Uji Koefisien Determinasi $\left(\mathbf{R}^{2}\right)$}

Analisis ini untuk mengetahui seberapa besar sumbangan atau kontribusi variabel bebas (Independent Variable) terhadap variabel terikat (Dependent Variable).

Tabel 4.13

Analisis Koefisien Determinasi $\left(\mathbf{R}^{2}\right)$

\begin{tabular}{|l|c|r|r|r|c|}
\multicolumn{7}{|c|}{ Model Summary $^{\mathbf{b}}$} \\
Model & $\mathrm{R}$ & $\begin{array}{c}\mathrm{R} \\
\text { Square }\end{array}$ & $\begin{array}{c}\text { Adjusted R } \\
\text { Square }\end{array}$ & $\begin{array}{c}\text { Std. Error of the } \\
\text { Estimate }\end{array}$ & $\begin{array}{c}\text { Durbin- } \\
\text { Watson }\end{array}$ \\
\hline 1 & $.764^{\mathrm{a}}$ & .583 & .550 & 1.8386 & 1.742 \\
\hline
\end{tabular}

a. Predictors: (Constant), Penagihan Pajak, Kewajiban Kepemilikan NPWP, Pemeriksaan Pajak

b. Dependent Variable: Penerimaan Pajak

Sumber : Data SPSS yang diolah 2018

Pada Tabel 4.13 terlihat nilai R-Square $\left(\mathrm{R}^{2}\right)$ sebesar 0,583 hingga dapat dihitung koefisien Determinasi $\left(\mathrm{R}^{2}\right)$ sebesar 58,3\%. Hal ini berarti 58,3\% dari variasi Penerimaan Pajak dapat dijelaskan oleh variabel Kewajiban Kepemilikan NPWP, Pemeriksaan Pajak, Penagihan Pajak. sedangkan sisanya sebesar $41,7 \%(100 \%-58,3 \%)$ diterangkan oleh variabel lain yang tidak diajukan dalam penelitian ini.

\section{Pembahasan}

Berdasarkan hipotesis yang telah dilakukan maka dapat diperoleh hasil sebagai berikut :

\section{Kewajiban Kepemilikan NPWP Terhadap Penerimaan Pajak}

Berdasarkan hasil penelitian yang telah dilakukan dapat dijelaskan bahwa semakin banyak NPWP yang dimiliki wajib pajak maka Penerimaan Pajak yang di terima akan semakin tinggi hal ini di buktikan secara statistic dengan menggunakan SPSS 22 didapati pada pengujian secara uji 
parsial (uji t) pada table 4.7 variabel Kewajiban Kepemilikan NPWP berpengaruh terhadap Penerimaan Pajak nilai t hitung sebesar 2.568 dengan nilai signifikan 0.014 dimana lebih kecil dari 0,05 maka variable kompetensi berpengaruh yang signifikan terhadap Penerimaan Pajak.

Menurut Waluyo (2009:30), setiap orang yang dengan sengaja tidak mendaftarkan diri untuk diberikan nomor pokok wajib pajak/NPWP, atau menyalahgunakan atau menggunakan tanpa hak NPWP sehingga menimbulkan kerugian bagi pendapatan negara, dipidana dengan pidana penjara paling singkat 6 (enam) bulan dan paling lama 6 (enam) tahun dan denda paling sedikit 2 (dua) kali jumlah pajak terutang dan paling banyak 4 (empat) kali jumlah pajak yang terutang. Dengan adanya kewajiban memiliki NPWP dan sanksi yg diberikan jika menyalahgunakan NPWP tersebut, maka wajib pajak harus membayar pajak terutangnya dengan demikian dapat meningkatkan penerimaan pajak.

Hasil penelitian ini konsisten dengan penelitian yang dilakukan oleh Setiawan (2008), yang menyatakan bahwa kewajiban kepemilikan NPWP berpengaruh secara signifikan terhadap penerimaan pajak. Untuk meningkatkan penerimaan negara tersebut maka pemerintah memberlakukan suatu kebijakan berupa keharusan dalam kepemilikan nomor pokok wajib pajak (NPWP) bagi masyarakat sebagai identitas wajib pajak yang memiliki banyak fungsi dalam bidang perpajakan maupun dalam bidang lainnya, salah satunya di bidang pajak adalah dalam hal pembayaran pajak.

\section{Pemeriksaan Pajak terhadap Penerimaan Pajak}

Berdasarkan pengujian hipotesis pengaruh Pemeriksaan Pajak terhadap Penerimaan Pajak dengan menggunakan uji $\mathrm{t}$ didapati nilai $\mathrm{t}$ hitung sebesar 7.121 dengan nilai signifikan 0.000 dimana lebih besar dari 0,05 maka variabel Pemeriksaan pajak berpengaruh signifikan terhadap Penerimaan Pajak. Jadi semakin tinggi pemeriksaan yang dilakukan oleh petugas pajak maka penerimaan pajak akan lebih meningkat.

Hal ini berarti bahwa semakin efektif seorang karyawan pemeriksa pajak dalam melakukan setiap tahapan-tahapan pemeriksaan pajak berdasarkan Keputusan Menteri Keuangan Nomor 545/KMK.04/2000 dapat meningkatkan penerimaan negara dalam sektor perpajakan. Peran pemeriksaan sebagai pendongkrak penerimaan pajak mengharuskan adanya pengawasan yang efektif terhadap pelaksanaan pemeriksaan pajak. Pengawasan atau pengendalian intern terhadap pemeriksaan pajak ini diimplementasikan dalam bentuk administrasi dan monitoring terhadap pemeriksaan pajak. Pemeriksaan pajak juga bertujuan untuk meredam kecurangan yang dilakukan wajib pajak untuk meminimalkan pajaknya. Dalam rangka pemenuhan hak dan kewajiban perpajakan wajib pajak, DJP melakukan pemeriksaan rutin kepada wajib pajak. Apabila telah dilakukan pemeriksaan dengan baik maka akan berdampak pada peningkatan penerimaan pajak negara.

Hasil penelitian ini konsisten dengan penelitian yang dilakukan oleh Sukirman (2011) yang menyatakan bahwa terdapat hubungan yang positif dan signifikan antara pemeriksaan pajak dengan penerimaan pajak. Pemeriksaan harus dapat mendorong kebenaran dan kelengkapan pelaporan penghasilan, penyerahan, pemotongan, dan pemungutan serta penyetoran pajak oleh WP (Sadhani, 2008:25).

\section{Penagihan Pajak terhadap Penerimaan Pajak}

Berdasarkan pengujian hipotesis pengaruh Pemeriksaan Pajak terhadap Penagihan Pajak dengan menggunakan uji $t$ didapati nilai t hitung sebesar 2.301 dengan nilai signifikan 0.027 dimana lebih besar dari 0,05 maka variabel Penagihan pajak berpengaruh signifikan terhadap Penerimaan Pajak. Jadi semakin tinggi Penagihan yang dilakukan oleh petugas pajak maka penerimaan pajak akan lebih meningkat.

Dengan adanya penagihan pajak, wajib pajak yang tidak mau membayar pajaknya dapat dipaksa untuk memenuhi kewajibannya dalam membayar pajak, sehingga dapat meningkatkan penerimaan pajak. Adapun serangkaian tindakan yang dilakukan oleh dirjen pajak agar wajib pajak melunasi hutang pajak dan biaya penagihan pajaknya, yaitu melalui tahapan-tahapan penagihan pajak. Serangkaian tahapan-tahapan agar wajib pajak melunasi hutang pajak dan biaya penagihan 
pajak dengan menegur atau memperingatkan, melaksanakan penagihan seketika dan sekaligus, memberitahukan surat paksa, mengusulkan pencegahan, melaksanakan penyitaan, melaksanakan penyanderaan, dan menjual barang yang telah disita. Diharapkan dengan serangkaian tahapantahapan tersebut dapat membuat wajib pajak patuh serta tepat waktu dalam membayar kewajiban perpajakannya, sehingga dapat menigkatkan penerimaan pajak.

Hasil penelitian ini konsisten dengan penelitian yang dilakukan oleh Gisijanto (2008:27), yang menyatakan bahwa terdapat hubungan yang positif dan signifikan antara penagihan pajak terhadap penerimaan pajak. Upaya penagihan dilakukan dengan memperhatikan optimalisasi jumlah wajib pajak yang ditagih. Optimalisasi tersebut dimaksudkan agar dapat menghasilkan penerimaan pajak dan juga mempertimbangkan segi keadilan dalam memperlakukan wajib pajak. Oleh sebab itu, diupayakan agar setiap wajib pajak akan mendapatkan giliran untuk diperiksa dalam rangka menguji pemenuhan kewajiban perpajakannya. Jika wajib pajak setelah ditagih pun belum memenuhi penagihan pajak maka KPP berhak menagih dengan surat paksa pajak sesuai dengan hukum perpajakan (Gisijanto, 2008:45).

Kewajiban Kepemilikan NPWP, Pemeriksaan Pajak, Penagihan Pajak terhadap Penerimaan Pajak

Berdasarkan pengujian hipotesis Pengaruh Kewajiban Kepemilikan NPWP, Pemeriksaan Pajak, Penagihan Pajak simultan atau bersama-sama terhadap Penerimaan Pajak dengan menggunakan uji F diperoleh nilai hipotesis pertama pada penelitian ini adalah Pengaruh Kewajiban Kepemilikan NPWP, Pemeriksaan Pajak, Penagihan Pajak secara simultan atau bersama-sama memiliki efek signifikan terhadap Penerimaan Pajak. Untuk mengetahui Pengaruh Kewajiban Kepemilikan NPWP, Pemeriksaan Pajak, Penagihan Pajak secara simultan atau bersama-sama menggunakan uji $\mathrm{F}$ dapat dilihat pada Tabel 4.8, diperoleh nilai $\mathrm{F}$ test $=17.717$ dengan tingkat signifikansi (sig) $=$ 0,000 . Karena nilai Signifikan $0,000<0,05$, dengan demikian Ho ditolak dan Ha diterima. maka model regresi yang diperoleh adalah signifikan atau dapat dikatakan Kewajiban Kepemilikan NPWP, Pemeriksaan Pajak, Penagihan Pajak secara bersama-sama berpengaruh secara signifikan terhadap Penerimaan Pajak.

\section{KESIMPULAN DAN SARAN}

\section{Kesimpulan}

Berdasarkan hasil penelitian yang telah dilakukan oleh penulis maka dapat ditarik kesimpulan sebagai berikut:

1. Berdasarkan hasil analisis dengan menggunakan kuesioner yang di sebarkan di Kantor Pelayanan Pajak Pratama Wilayah Batam Utara sebanyak 42 responden diperoleh bahwa Kewajiban Kepemilikan NPWP berpengaruh positif dan signifikan terhadap nilai Penerimaan Pajak dengan hasil pengujian regresi yang menunjukan nilai Sig sebesar $0.014<0.05$ yang berrarti bahwa semakin tinggi kepemilikan NPWP maka tingkat Penerimaaan Pajak yang akan semakin meningkat pula.

2. Berdasarkan hasil analisis dengan menggunakan kuesioner yang di sebarkan di Kantor Pelayanan Pajak Pratama Wilayah Batam Utara sebanyak 42 responden diperoleh bahwa Pemeriksaan Pajak berpengaruh positif dan signifikan terhadap Penerimaan Pajak dengan hasil pengujian regresi yang menunjukan nilai Sig sebesar $0.000<0.05$ yang berrarti bahwa semakin efektif Pemeriksaan pajak maka tingkat Penerimaaan Pajak yang akan semakin meningkat pula.

3. Berdasarkan hasil analisis dengan menggunakan kuesioner yang di sebarkan di Kantor Pelayanan Pajak Pratama Wilayah Batgam Utara sebanyak 42 responden diperoleh bahwa Penagihan Pajak berpengaruh positif dan signifikan terhadap Penerimaan Pajak dengan hasil pengujian regresi yang menunjukan nilai Sig sebesar $0.027<0.05$ yang berarti bahwa semakin tinggi penagihan pajak maka tingkat Penerimaaan Pajak yang akan semakin meningkat pula. 
Berdasarkan hasil uji $f$ atau hasil secara simultan diketahui varibel kewajiban kepemilikan NPWP, pemeriksaan pajak, penagihan pajak secara simultan mempunyai pengaruh terhadap penerimaan pajak.

\section{Saran}

Dari hasil penelitian ini ada beberapa saran yang dapat penulis sampaikan sebagai berikut:

1. Penelitian ini memiliki keterbatasan sehingga masih perlu untuk dapat disempurnakan. Penelitian ini juga menggunakan alat ukur kuesioner yang mungkin menimbulkan persepsi yang berbeda-beda, sehingga mungkin hasil penelitian tidak sesuai dengan keadaan sesungguhnya. Selain itu penelitian yang selanjutnya disarankan dapat menggunakan metode yang lain untuk menghindari bias persepsi dan juga disaarankan melakukan teknik wawancara untuk mendapatkan hasil penelitian yang lebih baik.

2. Hasil penelitian ini hanya mencerminkan kondisi pegawa pajak di Kantor Pelayanan Pajak Pratama pada Wilayah Batam Utara. Jumlah sampel untuk penelitian yang selanjutnya diharapkan dapat dikembangkan dan perlu mencermati waktu yang tepat dalam pembagian kuesioner agar memperoleh hasil yang maksimal.

3. Penelitian ini hanya menguji pengaruh variabel-variabel kewajiban kepemilikan NPWP, Pemeriksaan Pajak, Penagihan Pajak. Variabel-variabel lain yang mungkin berpengaruh terhadap Penerimaan Pajak tidak diuji dalam penelitian ini.

\section{E. DAFTAR PUSTAKA}

Etty Sri Wahyuni, Khaira Amalia Fachrudin \& mlys Syahputra Silalahi. 2019. An Empirical Study on Women's Financial Behavior: Case Study of Female Postgraduate Students in Medan, Indonesia. International Journal of Research Culture Society. 9 (11): 155-159.

Listyaningtyas, E.F. 2012. Efektivitas Pelaksanaan Pemeriksaan Dalam Rangka Meningkatkan Penerimaan Negara dari Sektor Pajak (Studi kasus di KPP Tulungagung). Universitas Negeri Surabaya.

Mardiasmo, (2011), Perpajakan, Edisi 3, Yogyakarta: Andi Offset

Marisa Herryanto dan Agus Arianto Toly. 2013. Pengaruh Kesadaran Wajib Pajak, Kegiatan Sosialisasi Perpajakan, Dan Pemeriksaan Pajak Terhadap Penerimaan Pajak Penghasilan Di Kpp Pratama Surabaya Sawahan. Tax \& Accounting Review, Vol.1(1).

Munari. 2005. Pengaruh Faktor Tax Payer Terhadap Keberhasilan Penerimaan PPH. Jurnal Eksekutif, Volume2 ,No.2.

Pardiat. 2008. Pemeriksaan Pajak. Jakarta: Mitra Wacana Media

Rahayu, Siti Kurnia. 2010. Pengaruh Penerapan Self Assessment System Dan Kualitas pelayanan Terhadap Kepatuhan Wajib Pajak. Jakarta.

Sugiyono. (2018). Metode Penelitian Kuantitatif. Bandung: Alfabeta.

Sukirman. 2011. Pengaruh Manajemen Pemeriksaan Pajak Terhadap Penerimaan Pajak (Studi Kasus Di KPP Semarang Timur). Jurnal Analisis Manajemen. Vol 5(1).

Vegirawati, Titin. 2011. Pengaruh Penerbitan Surat Tagihan Pajak Dengan Penerimaan Pajak Pada KPP Pratama Ilir Timur Palembang. Skripsi. Universitas Sjakhyakirti. (Tidak Dipublikasikan).

Zakiah M Syahab dan Hantoro Arief Gisijanto.2008. Pengaruh Penagihan Pajak Dan Surat Paksa Pajak Terhadap Penerimaan Pajak Penghasilan Badan. Jurnal Ekonomi Bisnis No.2 Vol.13 